\title{
Biologi Scelio pembertoni Timberlake (Hymenoptera: Scelionidae) pada telur Oxya japonica (Thunberg) (Orthoptera: Acrididae)
}

\author{
Biology of Scelio pembertoni Timberlake (Hymenoptera: Scelionidae) \\ on eggs of Oxya japonica (Thunberg) (Orthoptera: Acrididae)
}

\author{
Hapsah Adawiyatul Qodir*, Nina Maryana, Pudjianto \\ Departemen Proteksi Tanaman, Fakultas Pertanian, Institut Pertanian Bogor \\ Jalan Kamper, Kampus IPB Dramaga, Bogor 16680 \\ (diterima Januari 2017, disetujui Juni 2017)
}

\begin{abstract}
ABSTRAK
Parasitoid telur, Scelio pembertoni Timberlake (Hymenoptera: Scelionidae), merupakan endoparasitoid obligat pada telur Acrididae. Inang yang sering diparasitisasi oleh S. pembertoni ialah telur Oxya japonica (Thunberg) (Orthoptera: Acrididae). Penelitian ini bertujuan untuk mengetahui perkembangan stadia larva, lama hidup, dan keperidian, serta preferensi imago S. pembertoni terhadap umur telur inang yang berbeda. S. pembertoni diperoleh dari telur $O$. japonica yang diambil dari pertanaman talas dan talas liar di wilayah Bogor. Fase perkembangan $S$. pembertoni terdiri atas telur, stadia larva instar satu dan instar dua, stadia prapupa dan pupa, dan stadia imago. Larva instar satu bertipe teleaform dan berwarna putih transparan. Larva instar dua bertipe hymenopteriform dan berwarna putih transparan. Stadia pradewasa S. pembertoni di laboratorium berkisar antara 27-33 hari, dengan periode perkembangan telur, stadia instar satu, instar dua, prapupa, dan pupa ialah 1,80, 4,95, 4,25, 5,40, dan 12,85 hari untuk masing-masing stadia. Lama hidup betina adalah 7-17 hari, sedangkan lama hidup jantan adalah 3-11 hari. Rata-rata keperidian betina ialah 29,53 butir telur. Nisbah kelamin (jantan terhadap betina) $S$. pembertoni selama penelitian di laboratorium adalah 1 : 3,19 . Tingkat parasitisasi dan jumlah keturunan yang dihasilkan oleh $S$. pembertoni lebih tinggi pada telur berumur muda daripada umur telur inang yang lebih tua.
\end{abstract}

Kata kunci: belalang, parasitoid, siklus hidup, talas

\begin{abstract}
The egg parasitoid, Scelio pembertoni Timberlake (Hymenoptera: Scelionidae), is an obligate endoparasitoid of Acrididae. One of the hosts of S. pembertoni is the eggs of Oxya japonica (Thunberg) (Orthoptera: Acrididae). The objectives of this research were to determine the development stage of $S$. pembertoni, longevity and fecundity, and the preference of $S$. pembertoni against different host age. $S$. pembertoni were collected from O. japonica eggs taken from cultivated and wild taro fields in Bogor area. The life cycle of $S$. pembertoni consisted of egg stage, first and second instar larval stage, prepupal and pupal stage, and adult stage. The first instar larva was teleaform and transparent white. The second instar larva was hymenopteriform and transparent white. The immature stage of $S$. pembertoni lasted within 27-33 days under laboratory condition, and was consisted of egg development period, first instar stage, second instar stage, pre-pupal stage, and pupal stage was 1.8, 4.95, 4.25, 5.40, and 12.85 , respectively. Longevity of the adult females was 7-17 days, and longevity of the male adults was 3-11 days. The average fecundity of the females was 29.53 eggs. The sex ratio (male to female) of $S$. pembertoni during observation in the laboratory was $1: 3.19$. The parasitisation level and the number of offsprings produced by $S$. pembertoni was higher on younger host eggs than the older ones.
\end{abstract}

Key words: grasshopper, life cycle, parasitoid, taro

\footnotetext{
*Penulis korespondensi: Hapsah Adawiyatul Qodir. Program Studi Entomologi, Sekolah Pascasarjana, Fakultas Pertanian, Institut Pertanian Bogor, Jalan Kamper, Kampus IPB Dramaga, Bogor 16680, Tel: 0251-8629364, Faks: 0251-8629362; Email: adawiyatul.qodir@gmail.com. 


\section{PENDAHULUAN}

Parasitoid telur Scelio pembertoni Timberlake (Hymenoptera: Scelionidae) merupakan parasitoid yang termasuk Subfamili Scelioninae, dan tersebar di Indonesia dan Malaysia (Pemberton 1933; Dangerfield et al. 2001). Parasitoid ini bersifat soliter dan merupakan endoparasitoid obligat pada telur Acrididae (Dangerfield et al. 2001). Sifat S. pembertoni sebagai parasitoid telur ini memberikan banyak keuntungan dalam penggunaannya sebagai musuh alami. Menurut Romani et al. (2010), parasitoid telur merupakan agens hayati paling efektif dibandingkan dengan parasitoid lainnya, hal ini karena parasitoid telur dapat mengendalikan hama sebelum hama tersebut menjadi larva atau nimfa. Penggunaan parasitoid telur juga dinilai lebih menguntungkan karena parasitoid telur berukuran kecil sehingga cukup mudah dan murah untuk perbanyakan dalam skala besar di laboratorium (Wajnberg 2010). Pemberton (1933) melaporkan penggunaan $S$. pembertoni telah sukses digunakan sebagai agens pengendali hayati Oxya chinensis (Thunberg) (Orthoptera: Acrididae) di Hawaii (Pemberton 1933). Di Indonesia, populasi parasitoid ini ditemukan dominan memarasit telur Oxya japonica (Thunberg) (Yuliani 2003; Rasid 2014).

Inang yang sering diserang oleh parasitoid $S$. pembertoni adalah telur $O$. japonica yang merupakan hama pada tanaman padi. Kerusakan yang dapat ditimbulkan oleh serangan $O$. japonica pada tanaman padi, yaitu berupa lubang gigitan yang kecil dan menyebar pada helai daun bagian pucuk, tengah, dan pangkal daun. Serangan berat dapat menyebabkan hampir seluruh tepi daun habis dimakan hingga tulang daun (Yuliani 2003). Serangga ini bersifat polifag karena dapat memakan berbagai jenis tanaman yang berbeda, seperti apel, brokoli, kubis, kakao, jeruk, kelapa, kapas, sorgum, tebu, dan lain-lain (Willemse 2001). Banyaknya jenis tanaman inang memungkinkan keberadaan $O$. japonica di lapangan selalu ada dan menjadi salah satu hama dominan pada tanaman padi yang memasuki fase akhir vegetatif (Nurwahyudi 2003). Yuliani (2003) dan Rasid (2014) menyatakan bahwa O. japonica ditemukan meletakkan telur di dalam jaringan pelepah daun talas.
Menurut Pemberton (1933), S. pembertoni berkembang di dalam telur Oxya pada semua tahapan perkembangannya dan berpotensi untuk dikembangkan sebagai agens hayati $O$. japonica. Pemanfaatan parasitoid telur sebagai musuh alami harus didukung dengan pengetahuan dasar mengenai biologi dari parasitoid tersebut. Clausen (1940) menyatakan bahwa dalam pengendalian hayati serangga hama, pengetahuan tentang biologi dan perilaku musuh alami sangat penting. Saat ini, informasi mengenai parasitoid telur $S$. pembertoni di Indonesia masih terbatas. Oleh karena itu, untuk mengetahui potensi $S$. pembertoni sebagai agens pengendali hayati maka dibutuhkan informasi mengenai berbagai aspek biologi S. pembertoni di laboratorium. Penelitian ini bertujuan untuk mempelajari beberapa aspek biologi S. pembertoni. Aspek biologi yang diamati meliputi fase perkembangan, lama hidup imago (longevity), keperidian (fecundity), dan preferensi imago $S$. pembertoni dalam memilih inang, serta untuk mengetahui tingkat parasitisasinya di Bogor.

\section{BAHAN DAN METODE}

\section{Persiapan penelitian}

Perbanyakan tanaman inang dilakukan dengan menanam talas pada polybag berukuran $30 \mathrm{~cm}$ x $30 \mathrm{~cm}$. Tanaman talas ini berfungsi sebagai makanan (bagian daun) dan tempat peletakan telur (bagian pelepah daun) O. japonica. Perbanyakan serangga inang dilakukan di dalam kurungan berkasa dengan ukuran $50 \mathrm{~cm}$ x $50 \mathrm{~cm}$ x $50 \mathrm{~cm}$ yang sebelumnya sudah diisi tanaman talas. Telur yang ada di pelepah talas dimasukkan ke dalam wadah pemeliharaan untuk digunakan sebagai inang perbanyakan parasitoid. Wadah pemeliharaan ini berdiameter bawah $5 \mathrm{~cm}$ dan tinggi $6,5 \mathrm{~cm}$.

Perbanyakan parasitoid $S$. pembertoni dilakukan menggunakan imago yang diperoleh dari lapangan. Sampel diambil dari lahan pertanaman talas dan talas liar di Bogor. Imago parasitoid yang muncul dimasukkan ke dalam wadah pemeliharaan yang sebelumnya telah berisi telur O. japonica pada pelepah daun talas. Wadah pemeliharaan diberi alas kapas dan disemprot dengan sedikit air agar tempat pemeliharaan telur tetap lembap dan tidak kering. Sebagai pakan 
imago parasitoid, pada bagian dinding wadah pemeliharaan dioleskan madu $30 \%$. Suhu dan kelembapan rata-rata di laboratorium selama pengamatan adalah $28,04{ }^{\circ} \mathrm{C}$ dan $66,22 \%$. Penelitian dilaksanakan di Laboratorium Biosistematika Serangga, Departemen Proteksi Tanaman, Fakultas Pertanian, Institut Pertanian Bogor. Kegiatan penelitian dilaksanakan pada bulan Maret 2015Juli 2016.

\section{Pengamatan biologi parasitoid}

Pengamatan pada fase pradewasa. Imago betina parasitoid secara individu dimasukkan ke dalam wadah pemeliharaan yang sudah diisi dengan telur $O$. japonica pada pelepah daun talas. Pemaparan telur dilakukan selama 24 jam. Pengamatan dilakukan dengan cara membedah telur yang sudah dipaparkan setiap hari sampai ditemukan 20 telur yang terparasit untuk dapat satu data. Pembedahan telur terparasit dilakukan pada umur 0-26 hari setelah pemaparan (HSP). Pengamatan meliputi ciri-ciri morfologi pada setiap fase pradewasa serta ukuran mandibel pada fase larva. Pengukuran tubuh dan mandibel dilakukan menggunakan mikroskop stereo dan mikroskop compound yang terhubung dengan kamera Dino lite 2.0. Pendugaan stadium pradewasa dilakukan dengan menghitung rata-rata lama mencapai fase selanjutnya dikurang dengan rata-rata lama mencapai fase sebelumnya.

Pengamatan pada fase imago. Pengamatan pada fase imago parasitoid terdiri atas pengamatan ciriciri morfologi, keperidian imago betina, dan nisbah kelamin yang dihasilkan. Pengamatan keperidian dilaksanakan dengan cara memasukkan imago betina parasitoid secara individu ke dalam wadah pemeliharaan yang di dalamnya sudah tersedia telur $O$. japonica yang berumur satu hari atau kurang. Pemaparan telur dilakukan selama satu hari. Telur yang sudah dipaparkan dipindahkan ke wadah pemeliharaan telur yang baru. Penggantian telur inang dilakukan setiap hari hingga imago betina parasitoid mati. Telur pada pelepah daun talas yang sudah dipaparkan dibedah dan dicatat jumlah fase pradewasa yang ada di dalam telur inang. Pengamatan dilakukan dengan 19 kali ulangan imago betina yang digunakan.

Pengamatan nisbah kelamin menggunakan imago yang sudah kopulasi. Imago tersebut dimasukkan ke dalam wadah pemeliharaan yang sudah berisi telur $O$. japonica pada pelepah daun talas. Setelah 24 jam, telur yang sudah dipaparkan disimpan di wadah pemeliharaan dan ditunggu hingga imago keturunannya muncul. Pemaparan dilakukan hanya satu kali pemaparan. Keturunan yang muncul tersebut diamati jenis kelaminnya untuk melihat perbandingan banyaknya jumlah jantan dan betina.

\section{Preferensi imago $S$. pembertoni terhadap umur telur inang yang berbeda}

Imago betina $S$. pembertoni yang sudah kopulasi dimasukkan ke dalam wadah pemeliharaan secara individu dan diberi pakan larutan madu $30 \%$ yang dioleskan pada dinding wadah. Sebelumnya ke dalam wadah tersebut dimasukkan telur $O$. japonica pada pelepah daun talas dengan umur telur yang berbeda. Sebagai perlakuan, pada masing-masing wadah, telur yang baru diletakkan (berumur 0 hari), 1, 2, 3, dan 4 hari. Lama pemaparan telur inang dilakukan selama satu hari dan hanya dilakukan satu kali pemaparan. Telur $O$. japonica yang telah dipaparkan kemudian dipelihara di dalam wadah pemeliharaan dan ditunggu hingga imago parasitoid keluar. Pengamatan meliputi jumlah parasitoid yang muncul dan tingkat parasitisasinya.

\section{Parasitisasi S. pembertoni di lapangan}

Pengambilan sampel di lapangan dilakukan di 6 Kecamatan, yaitu Kecamatan Tamansari, Cijeruk, Tenjolaya, Ciomas, Bogor Barat, dan Bogor Selatan. Pengambilan sampel pada petak contoh dilakukan secara purposive dengan mengambil sejumlah pelepah daun talas yang memperlihatkan gejala peletakan telur $O$. japonica. Pelepah daun talas yang menunjukkan tanda peneluran dipotong dengan panjang sekitar $9 \mathrm{~cm}$. Potongan pelepah tersebut kemudian disimpan di dalam wadah pemeliharaan. Setiap wadah pemeliharaan hanya diisi dengan satu kelompok telur inang agar mudah saat pengamatan. Pengamatan dilakukan setiap hari dan dihitung tingkat parasitisasi dari $S$. pembertoni.

parasitisasi $=\frac{\text { Jumlah telur inang terparasit }}{\text { Jumlah telur inang total }} \times 100 \%$

\section{Analisis data}

Data pengamatan biologi parasitoid berupa data deskriptif. Uji preferensi imago $S$. pembertoni 
terhadap umur telur inang yang berbeda menggunakan analisis ragam (ANOVA), yang dilanjutkan dengan uji Duncan pada taraf 5\% dengan menggunakan bantuan program Microsoft Office Excel 2010 dan Statistical Analysis System (SAS) 9.1.3.

\section{HASIL}

\section{Ciri-ciri morfologi S. pembertoni}

Tubuh imago S. pembertoni berwarna hitam dari bagian ujung kepala hingga ke ujung metasoma (Gambar 1). Skapus pada antena dan tegula berwarna cokelat kemerahan. Bagian mandibel berwarna cokelat kemerahan dengan bagian pangkal mandibel berwarna hitam. Tungkai berwarna cokelat kemerahan. Pada tibia terdapat taji, dengan formula taji 1-1-1. Sayap kusam, dengan garis hialin longitudinal pada bagian tengah sayap depan (Gambar 2A). Vena stigma pada sayap depan berbentuk silinder, terlihat jelas dan melengkung, serta runcing pada bagian ujung. Posisi vena stigma berdekatan dengan marjin depan (Gambar 2C). Metasoma berbentuk fusiform, terdiri atas enam ruas. Tergit pertama (T1) sedikit lebih lebar di bagian dasarnya kirakira 1,6 kali lebar bagian apikal. Tergit ke-dua (T2) lebih pendek dari tergit ke-tiga (T3). T3 merupakan tergit paling panjang. Tergit ke-empat (T4) lebih panjang dari tergit ke-lima (T5). Tergit ke-enam (T6) hampir sama dengan panjang T1. T1 sampai T5 dengan garis-garis memanjang. T2 mirip dengan T3, akan tetapi pada T2 terdapat garis halus yang kurang jelas dan terlihat seperti garis segitiga di bagian tengah. Antena imago betina terdiri atas 12 ruas, sedangkan antena jantan terdiri atas 10 ruas. Metasoma imago betina melebar dengan bagian ujung yang meruncing, sedangkan metasoma jantan terlihat lebih ramping dan silinder dengan ujung yang menumpul. Ratarata panjang dan lebar tubuh imago betina adalah $4,29 \pm 0,04$ dan $0,76 \pm 0,01 \mathrm{~mm}$, dengan rata-rata panjang rentang sayap $5,39 \pm 0,06 \mathrm{~mm}$. Ratarata panjang dan lebar tubuh imago jantan adalah $4,15 \pm 0,03$ dan $0,75 \pm 0,01 \mathrm{~mm}$, dengan rata-rata panjang rentang sayap 5,32 $\pm 0,04 \mathrm{~mm}$.

Telur $S$. pembertoni berwarna putih berbentuk panjang dengan bagian posterior yang semakin mengecil (Gambar 3A). Ukuran panjang ratarata telur adalah $0,87 \pm 0,01 \mathrm{~mm}$ dan lebar $0,07 \pm$ $0,00 \mathrm{~mm}$ (Tabel 1). Tubuh larva instar satu berwarna putih transparan, terbagi atas dua bagian, yaitu abdomen dan sefalotoraks (Gambar 3B). Karakteristik morfologi instar satu, yaitu memiliki abdomen yang berbentuk bulat dan cekung dengan ruas terakhir abdomen (cauda)
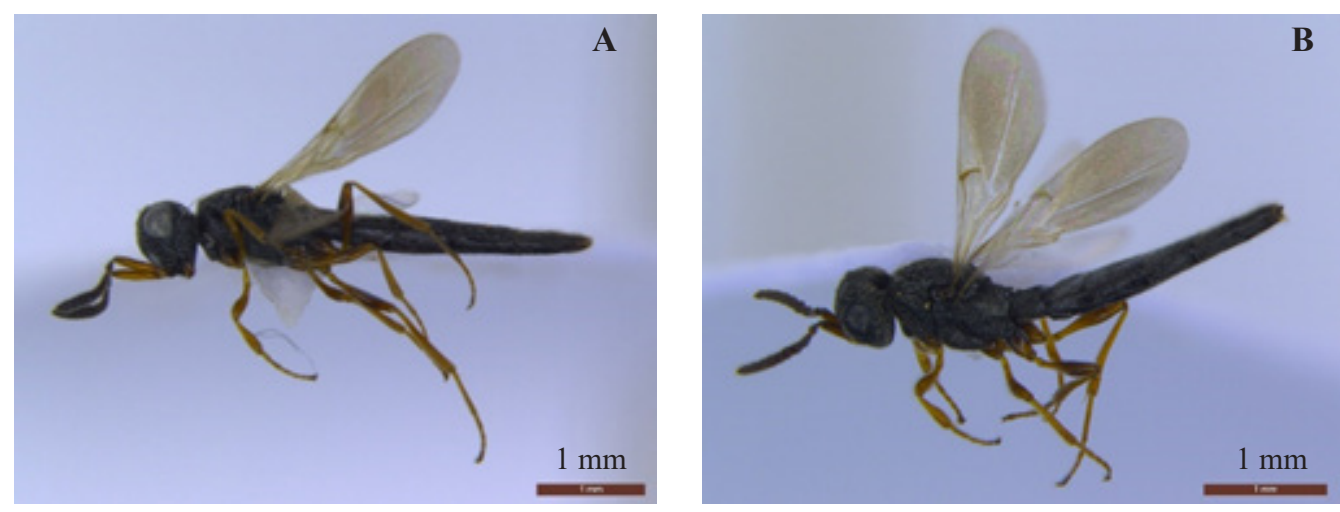

Gambar 1. Imago Scelio pembertoni. A: betina; B: jantan.

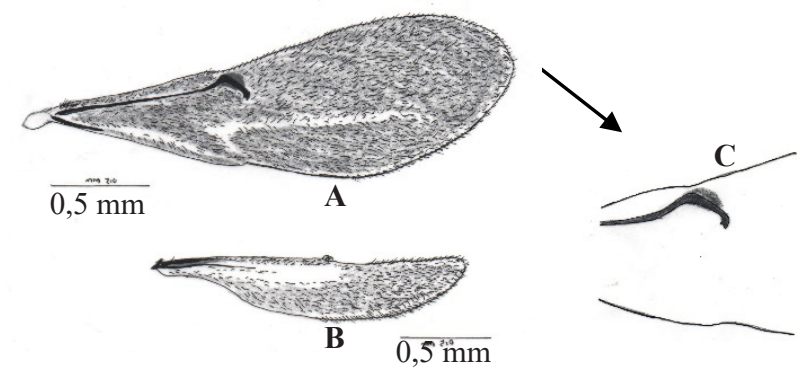

Gambar 2. Sayap Scelio pembertoni. A: sayap depan; B: sayap belakang; C: vena stigma. 
melengkung, seperti kait dan terdapat rambutrambut halus yang mengelilingi bagian atas abdomen. Larva instar satu akhir berbentuk seperti buah pir dengan bagian abdomen yang besar, sedangkan bagian kepala terlihat lebih kecil (Gambar 3C). Panjang tubuh instar satu berkisar antara 0,33-1,82 $\mathrm{mm}$ dengan lebar tubuh berkisar antara $0,10-0,98 \mathrm{~mm}$ (Tabel 1). Mandibel larva instar satu terlihat jelas dan berbentuk seperti kait (Gambar 4A). Rata-rata panjang mandibel instar satu adalah 0,101 $\pm 0,001 \mathrm{~mm}$.

Perubahan fase larva instar satu ke instar dua ditandai dengan ganti kulit, hal ini dapat dilihat dari adanya eksuvia instar satu pada bagian cauda instar dua (Gambar 3D). Larva instar dua awal berwarna putih transparan dan menjadi kuning pucat pada saat fase instar dua akhir. Tubuh larva instar dua berbentuk silinder dengan peruasan tubuh tidak terlihat jelas. Panjang tubuh larva instar dua berkisar antara 1,19-5,96 mm dengan lebar tubuh berkisar antara 0,68-2,25 mm (Tabel 1). Mandibel instar dua tidak terlihat dengan jelas, berbentuk seperti kait yang runcing dan tipis (Gambar 4B). Rata-rata panjang mandibel instar dua adalah $0,07 \pm 0,001 \mathrm{~mm}$.
Tubuh prapupa berwarna putih kekuningan, bentuk tubuh berkerut-kerut. Kerutan ini terlihat pada permukaan luar tubuh, bagian ujung anterior agak melengkung serta tidak ada lagi aktivitas makan (Gambar 3E). Prapupa akhir ditandai dengan terbentuknya lekukan calon bagian tubuh , seperti bagian kepala dan metasoma. Kisaran panjang tubuh fase prapupa adalah $3,04-5,65 \mathrm{~mm}$ dan lebar tubuh 0,78-1,57 mm (Tabel 1).

Pupa awal berwarna putih kekuningan dengan bagian bakal mata berwarna cokelat muda. Menjelang menjadi imago hampir seluruh tubuh berwarna hitam dan bakal sayap sudah semakin berkembang, dengan bagian samping metasoma masih putih (Gambar 3F). Fase pupa ditandai dengan peruasan bagian tubuh antara kepala, mesosoma, dan metasoma yang terlihat jelas, serta terdapat bakal embelan-embelan tubuh seperti bakal antena dan bakal tungkai. Fase pupa ini juga dapat ditandai dengan terdapatnya mekonium pada bagian ujung posterior pupa. Mekonium berwarna cokelat dan terletak di ujung posterior metasoma. Panjang pupa berkisar antara 3,60-5,17 mm, dan lebar 0,71-1,23 mm (Tabel 1).
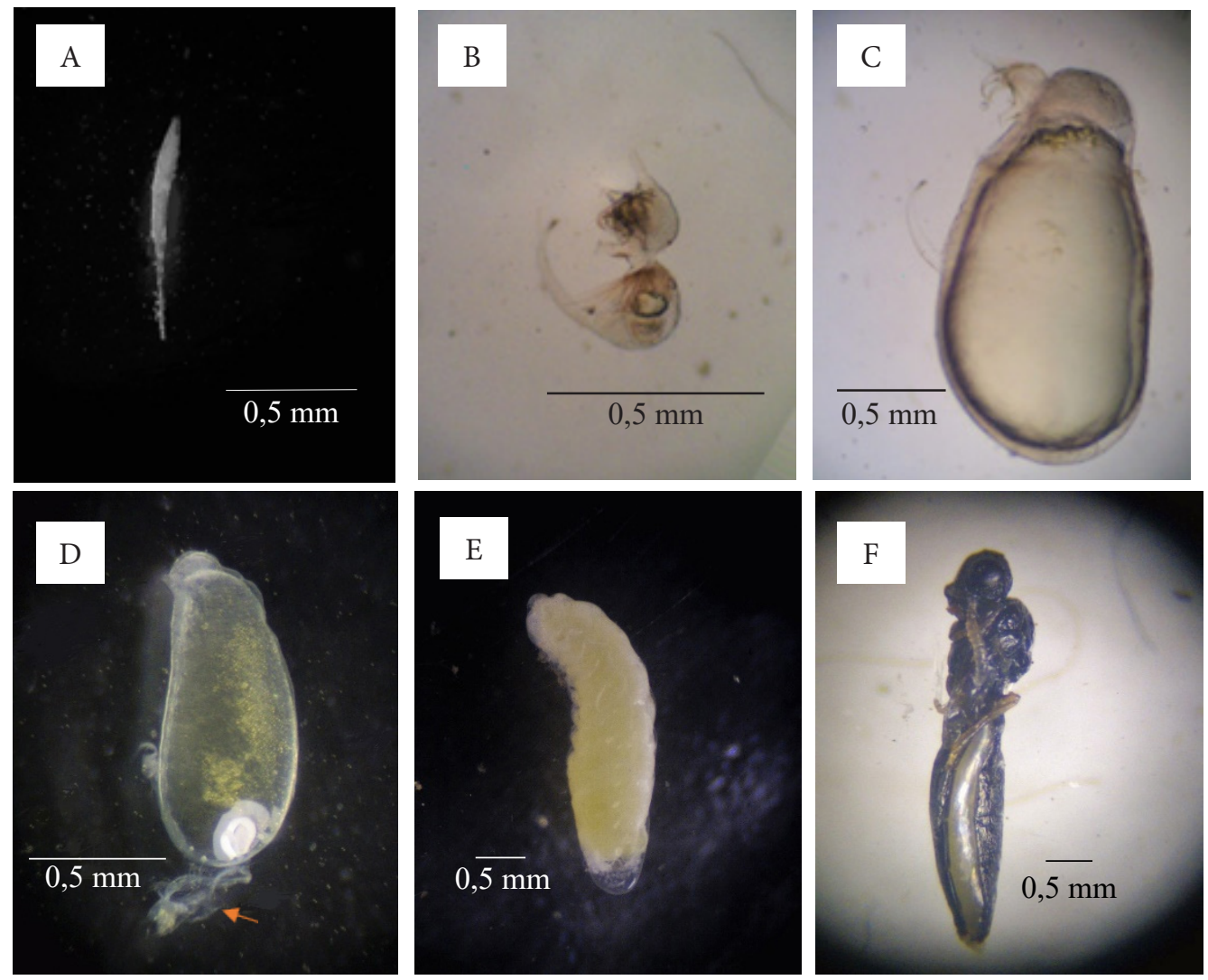

Gambar 3. Bentuk fase perkembangan pradewasa Scelio pembertoni; A: telur; B: instar satu awal (2 HSP); C: instar satu akhir (7 HSP); D: instar dua awal (8 HSP); E: prapupa (12 HSP); F: pupa (26 HSP). 


\section{Lama perkembangan $S$. pembertoni}

Stadium pradewasa $S$. pembertoni di laboratorium berkisar antara 27-33 hari. Masa perkembangan telur dari diletakkan hingga menjadi larva instar satu berlangsung cukup singkat, dengan rata-rata 1,8 hari. Stadium larva instar satu dan dua berturut-turut 4,95 dan 4,25 hari. Stadium prapupa mencapai 5,40 hari dan stadium pupa selama 12,85 hari (Tabel 2). Lama hidup imago S. pembertoni berkisar antara 3-17 hari. Rata-rata lama hidup imago betina adalah $10,42 \pm 0,79$ hari, dan rata-rata lama hidup imago jantan adalah 6,94 $\pm 0,43$ hari (Tabel 3).

Keperidian, jumlah keturunan, dan nisbah kelamin

Keperidian rata-rata betina selama hidupnya mencapai 29,53 $\pm 2,35$ butir telur (Tabel 3). Masa praoviposisi betina berlangsung sangat singkat atau kurang dari satu hari. Masa oviposisi berkisar antara 2-7 hari dan masa pascaoviposisi berkisar antara 1-7 hari. Nisbah kelamin jantan dan betina yang dihasilkan selama pengamatan di laboratorium adalah $1: 3,19$.

Jumlah keturunan yang dihasilkan per hari berdasarkan pada pengamatan teluryang diletakkan dan jumlah keturunan yang berhasil menjadi imago pada pengamatan hari ke-dua meningkat, dan kemudian terjadi penurunan di hari berikutnya (Gambar 5). Jumlah keturunan yang dihasilkan pada kedua jenis pengamatan ini menunjukkan nilai yang sedikit berbeda. Keperidian rata-rata berdasarkan pada jumlah telur yang diletakkan lebih banyak daripada keperidian berdasarkan jumlah keturunan yang berhasil menjadi imago (Tabel 3).

\section{Perilaku peletakan telur $S$. pembertoni}

Superparasitisme pada $S$. pembertoni. $S$. pembertoni dapat meletakan telur lebih dari
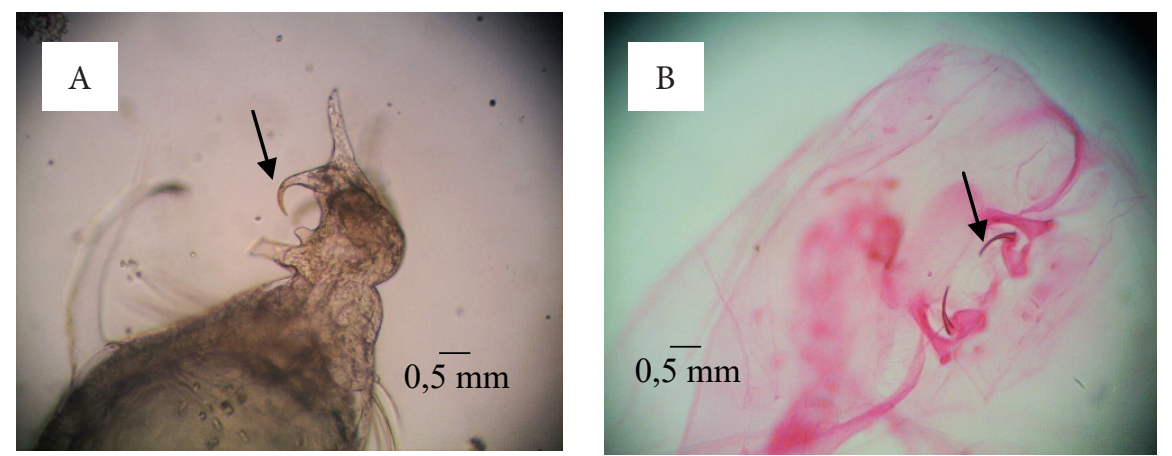

Gambar 4. Bentuk mandibel larva Scelio pembertoni. A: instar satu; B: instar dua.

Tabel 1. Ukuran pradewasa parasitoid Scelio pembertoni (rata-rata $\pm \mathrm{SE}$ )

\begin{tabular}{lccccc}
\hline Fase perkembangan & $\begin{array}{c}\text { Panjang rata-rata } \\
(\mathrm{mm})\end{array}$ & $\begin{array}{c}\text { Kisaran panjang } \\
(\mathrm{mm})\end{array}$ & $\begin{array}{c}\text { Lebar rata-rata } \\
(\mathrm{mm})\end{array}$ & $\begin{array}{c}\text { Kisaran lebar } \\
(\mathrm{mm})\end{array}$ & $\begin{array}{c}\mathrm{N} \\
(\mathrm{individu})\end{array}$ \\
\hline Telur & $0,87 \pm 0,01$ & $0,67-0,96$ & $0,07 \pm 0,00$ & $0,05-0,10$ & 36 \\
Larva instar 1 & $0,67 \pm 0,03$ & $0,33-1,82$ & $0,36 \pm 0,02$ & $0,10-0,98$ & 119 \\
Larva instar 2 & $3,53 \pm 0,10$ & $1,19-5,96$ & $1,13 \pm 0,02$ & $0,68-2,25$ & 85 \\
Prapupa & $4,16 \pm 0,04$ & $3,04-5,65$ & $1,14 \pm 0,01$ & $0,78-1,57$ & 108 \\
Pupa & $4,43 \pm 0,02$ & $3,60-5,17$ & $0,95 \pm 0,01$ & $0,71-1,23$ & 163 \\
\hline
\end{tabular}

Tabel 2. Stadium perkembangan fase pradewasa Scelio pembertoni

\begin{tabular}{lcc}
\hline Pengamatan & $\begin{array}{c}\text { Lama stadia } \\
\text { (hari) }\end{array}$ & $\begin{array}{c}\text { N } \\
\text { (individu) }\end{array}$ \\
\hline Masa perkembangan pradewasa & 29,25 & 20 \\
Telur & 1,80 & 20 \\
Larva instar 1 & 4,95 & 20 \\
Larva instar 2 & 4,25 & 20 \\
Prapupa & 5,40 & 20 \\
Pupa & 12,85 & 20 \\
\hline
\end{tabular}


satu telur pada satu inang. Kisaran jumlah telur yang dapat diletakkan dalam satu inang adalah 1-4 telur per inang. Tingkat superparasitisme di laboratorium mencapai $16 \%$, dengan nilai terendah terjadi pada peletakan 4 telur per inang (1\%) dari 367 telur inang yang diparasit (Gambar 6).

Preferensi imago $S$. pembertoni terhadap umur telur inang yang berbeda. Secara umum $S$. pembertoni dapat memarasit semua umur telur inang yang dipaparkan (umur $0-4$ hari). Hasil pemaparan telur yang baru diletakkan serta telur umur 1 dan 2 hari menunjukkan hasil tidak berbeda nyata terhadap jumlah keturunan dan tingkat parasitisasinya. Perbedaan terlihat pada pemaparan umur inang 4 hari dengan rata-rata jumlah keturunan dan tingkat parasitisasi yang dihasilkan terrendah, yaitu 2,20 $\pm 1,1$ dan $24,4 \pm 11,5 \%$. (Tabel 4).

\section{Tingkat parasitisasi $S$. pembertoni di lapangan}

Tingkat parasitisasi $S$. pembertoni di lapangan berdasarkan kelompok telur, tertinggi terjadi pada pengamatan di Kecamatan Bogor Selatan yang mencapai 34,28\%, sedangkan tingkat parasitisasi terrendah terjadi pada tiga lokasi pengamatan, yaitu lokasi Tamansari, Cijeruk, dan Ciomas, yaitu sebesar $0 \%$ (Tabel 5). Begitu pula berdasarkan pada jumlah telur yang terparasit, Lokasi Bogor Selatan menujukkan nilai tingkat parasitisasi tertinggi, yaitu $14,78 \%$.

\section{PEMBAHASAN}

Berdasarkan pada deskripsi karakter morfologi yang disusun oleh Timberlake (1931) dan Dangerfield et al. (2001), Scelio yang digunakan pada penelitian ini lebih mirip dengan S. pembertoni daripada Scelio murai Watanabe dan Scelio tsuruokensis Watanabe sehingga dapat dikatakan bahwa parasitoid tersebut adalah $S$. pembertoni. Menurut Timberlake (1931) dan Dangerfield et al. (2001), S. pembertoni diketahui sebagai parasitoid telur dari $O$. chinensis dan $O$. japonica yang berasal dari wilayah Indonesia dan Malaysia.

Fase perkembangan S. pembertoni terdiri atas telur, larva instar satu dan dua, prapupa, pupa, dan imago. Tipe telur S. pembertoni termasuk ke dalam tipe telur acuminate. Tipe telur acuminate adalah tipe telur dengan karakteristik telur yang panjang dan sempit serta teradaptasi pada serangga dengan ovipositor yang panjang (Zuparko 2008). Menurut Field \& Austin (1994), panjang ovipositor pada

Tabel 3. Lama hidup, masa oviposisi dan pascaoviposisi, dan keperidian imago Scelio pembertoni

\begin{tabular}{lcc}
\hline Pengamatan & Rata-rata \pm SE & N (individu) \\
\hline Lama hidup (hari) & & \\
$\quad$ Imago betina & $10,42 \pm 0,79$ & 19 \\
$\quad$ Imago jantan & $6,94 \pm 0,43$ & 19 \\
Masa oviposisi (hari) & $4,00 \pm 0,28$ & 19 \\
Masa pascaoviposisi (hari) & $2,63 \pm 0,47$ & 19 \\
Keperidian & & \\
$\quad$ Jumlah telur yang diletakkan (telur/betina) & $29,53 \pm 2,35$ & 19 \\
$\quad$ Jumlah keturunan yang berhasil menjadi imago (individu/betina) & $23,27 \pm 2,19$ & 15 \\
\hline
\end{tabular}

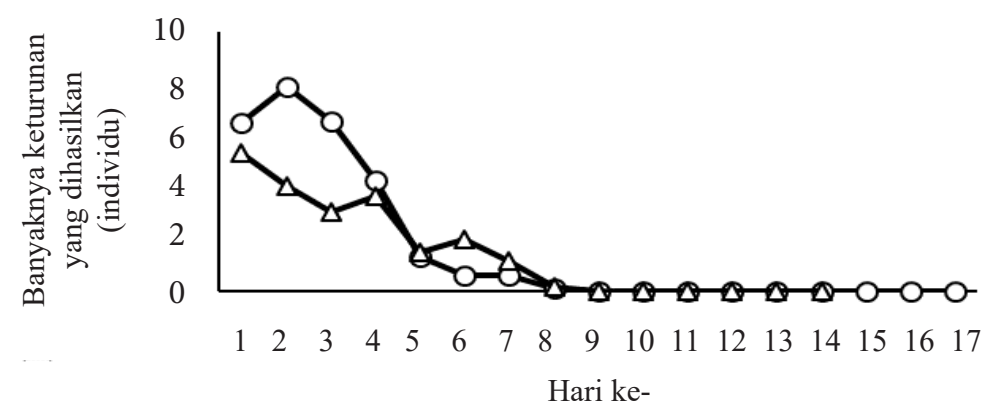

Gambar 5. Rata-rata keturunan yang dihasilkan betina per hari berdasarkan pada telur yang diletakkan $\left(\multimap \boldsymbol{\prime}^{\prime}\right)$ dan imago yang dihasilkan $(\neg-)$. 
Scelio fulgidus Crawford secara keseluruhan dapat mencapai 3,5 kali panjang metasoma. Perkembangan larva dapat dibedakan berdasarkan pada perbedaan bentuk morfologi dan adanya eksuvia instar sebelumnya yang menempel pada tubuh instar berikutnya sehingga fase larva $S$. pembertoni diduga terdiri atas dua instar. Pickford (1964) menyatakan bahwa fase larva Scelio opacus (Provancher) (S. calopteni Riley) terdiri atas dua instar. Tipe perkembangan $S$. pembertoni bersifat hipermetamorfosis karena bentuk morfologi pada instar pertama berbeda dengan instar selanjutnya (Rasid 2014). Larva instar satu S. pembertoni termasuk dalam tipe larva teleaform (Clausen 1940). Larva instar satu memiliki mandibel yang terlihat jelas dan besar. Mandibel ini digunakan untuk menghancurkan embrio inang dan untuk

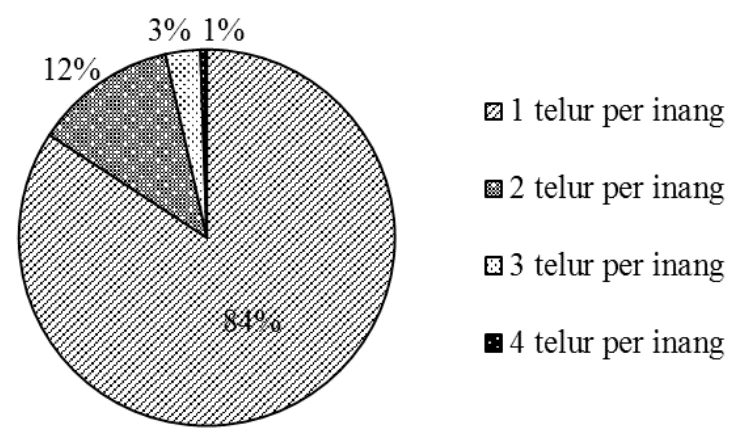

Gambar 6. Persentase jumlah telur Scelio pembertoni per inang. bersaing dengan larva lainnya yang ada di dalam telur inang yang sama (Clausen 1940; Pickford 1964; Salt 1961). Tipe larva instar dua adalah larva hymenopteriform (Clausen 1940; Dangerfield et al. 2001), yaitu tubuh berbentuk silinder dengan peruasan tubuh tidak terlihat jelas, bagian kepala dan abdomen dapat dibedakan dengan melihat posisi eksuvia instar satu yang terletak di bagian ujung abdomen. Berbeda dengan instar satu, mandibel instar dua tidak terlihat dengan jelas dengan ukuran yang lebih kecil dan lebih ramping daripada mandibel instar satu. Menurut Clausen (1940), pupa $S$. pembertoni tergolong tipe pupa eksarata.

Stadium pradewasa $S$. pembertoni di laboratorium hasil pengamatan memiliki hasil yang berbeda dengan hasil penelitian Rasid (2014), yang menyatakan bahwa lama stadia pradewasa $S$. pembertoni berkisar antara 26-30 hari. Perbedaan ini diduga ada kaitannya dengan kondisi suhu dan kelembapan yang berbeda selama penelitian. Masa perkembangan telur $S$. pembertoni berlangsung cukup singkat. Hal ini sesuai dengan Dangerfield et al. (2001), yang menyatakan bahwa perkembangan telur Scelio spp. berlangsung singkat (kurang dari 3 hari). Fase perkembangan terlama dari seluruh tahapan perkembangan pradewasa S. pembertoni terjadi pada fase pupa. Waktu kemunculan imago

Tabel 4. Pengaruh umur telur inang terhadap jumlah keturunan parasitoid dan tingkat parasitisasinya

\begin{tabular}{lcccc}
\hline $\begin{array}{l}\text { Umur telur inang } \\
\text { (hari) }\end{array}$ & $\begin{array}{c}\text { Imago yang } \\
\text { dipaparkan }\end{array}$ & $\begin{array}{c}\text { Rata-rata telur yang } \\
\text { diletakan (individu) }\end{array}$ & $\begin{array}{c}\text { Rata-rata tingkat } \\
\text { parasitisasi (\%) }\end{array}$ & $\begin{array}{c}\text { Rata-rata telur inang yang } \\
\text { diumpankan (butir) }\end{array}$ \\
\hline 0 & 5 & $7,40 \pm 1,33 \mathrm{a}$ & $100,0 \pm 00 \mathrm{a}$ & 7,40 \\
1 & 5 & $7,00 \pm 1,05 \mathrm{a}$ & $90,0 \pm 10 \mathrm{ab}$ & 8,00 \\
2 & 5 & $5,80 \pm 1,30 \mathrm{ab}$ & $100,0 \pm 00 \mathrm{a}$ & 5,80 \\
3 & 11 & $3,36 \pm 0,85 \mathrm{bc}$ & $53,8 \pm 14,3 \mathrm{bc}$ & 6,73 \\
4 & 10 & $2,20 \pm 1,10 \mathrm{c}$ & $24,4 \pm 11,5 \mathrm{c}$ & 8,20 \\
\hline
\end{tabular}

*Angka-angka pada kolom yang sama yang diikuti oleh huruf yang sama tidak berbeda nyata pada taraf uji 5\% (uji selang berganda Duncan).

Tabel 5. Tingkat parasitisasi Scelio pembertoni di lapangan

\begin{tabular}{lcccc}
\hline Lokasi (Kecamatan) & $\begin{array}{c}\text { Jumlah } \\
\text { kelompok telur }\end{array}$ & $\begin{array}{c}\text { Tingkat parasitisasi } \\
\text { kelompok telur }(\%)\end{array}$ & $\begin{array}{c}\text { Jumlah telur } \\
\text { (butir) }\end{array}$ & $\begin{array}{c}\text { Tingkat parasitisasi } \\
\text { telur }(\%)\end{array}$ \\
\hline Tamansari & 0 & 0 & 0 & 0 \\
Cijeruk & 40 & 0 & 210 & 0 \\
Tenjolaya & 28 & 7,14 & 222 & 6,31 \\
Ciomas & 19 & 0 & 114 & 0 \\
Bogor Barat & 1138 & 4,98 & 6073 & 5,32 \\
Bogor Selatan & 35 & 34,28 & 203 & 14,78 \\
\hline
\end{tabular}


jantan lebih cepat daripada imago betina. Hal ini sesuai dengan pernyataan Dangerfield et al. (2001). Kemunculan imago jantan terlebih dahulu dikarenakan imago jantan menunggu kemunculan imago betina agar begitu imago betina muncul dapat langsung terjadi kopulasi.

Reproduksi imago $S$. pembertoni bersifat arenotoki. Pada reproduksi arenotoki, apabila imago betina tidak melakukan kopulasi maka akan menghasilkan keturunan jantan, sedangkan jika imago betina melakukan kopulasi maka akan menghasilkan keturunan jantan dan betina (Dangerfield et al. 2001). Imago betina memiliki masa praoviposisi yang sangat singkat sehingga betina yang baru muncul dapat langsung meletakkan telur.

Jumlah keturunan yang dihasilkan berdasarkan pada jumlah telur yang diletakan dan jumlah keturunan yang berhasil menjadi imago memiliki nilai yang sedikit berbeda. Diduga hal itu ada kaitannya dengan imago $S$. pembertoni yang dapat meletakkan telur lebih dari satu telur pada satu inang, akan tetapi parasitoid yang dapat berkembang hingga menjadi imago hanya satu individu. Menurut Salt (1961), pada parasitoid soliter hanya satu parasitoid per inang yang dapat berkembang dan larva lainnya akan mati selama proses berkembangannya, sebagian besar terjadi karena adanya serangan kontak antara mandibel larva yang saling bersaing pada larva instar pertama. Dilihat berdasarkan nisbah kelaminnya, proporsi imago betina lebih banyak daripada imago jantan. Hal yang sama juga dinyatakan oleh Pemberton (1933).

Peletakan telur lebih dari satu telur pada satu inang disebut dengan perilaku superparasitisme. Perilaku ini pada S. pembertoni juga telah dilaporkan oleh Pemberton (1933). Terjadinya peletakan telur lebih dari satu telur parasitoid dalam satu telur inang dapat disebabkan oleh banyak faktor, salah satunya adalah ketersediaan telur inang dalam satu kelompok telur inang yang tidak sebanding dengan banyaknya telur parasitoid yang matang atau yang siap diletakkan oleh imago parasitoid. Faktor lainnya juga yang mempengaruhi adalah kemungkinan imago parasitoid beranggapan bahwa telur yang pertama diletakkan memiliki angka harapan hidup yang kecil sehingga parasitoid meletakkan telur kembali untuk dapat memaksimumkan tingkat harapan hidup dari keturunannya (Godfray 1994).

Perilaku imago $S$. pembertoni dalam meletakkan telur lebih menyukai telur inang yang berumur muda juga dilaporkan oleh Pemberton (1933). Menurut Godfray (1994), umur inang pada fase inang yang tidak tumbuh (telur atau pupa) berpengaruhterhadapparasitoid.Apabila parasitoid menyerang pada umur tua, ada kemungkinan inang tersebut akan menetas sebelum parasitoid menyelesaikan fase hidupnya. Salah satu faktor yang mempengaruhi pemilihan telur inang muda oleh parasitoid adalah perkembangan embrio inang. Hal ini karena, embrio inang yang berkembang dapat menghabiskan nutrisi yang tersimpan di dalam telur sehingga telur tua merupakan inang dengan kualitas yang rendah. Selain itu, pemilihan telur inang yang berumur muda lebih menguntungkan karena memiliki kualitas nutrisi yang lebih baik untuk menunjang perkembangan keturunan parasitoid dibandingan dengan telur inang yang lebih tua (Peñaflor et. al 2012).

Tingkat parasitisasi S. pembertoni di lapangan sangat beragam, hal ini dapat disebabkan oleh banyak faktor. Rendahnya tingkat parasitisasi $S$. pembertoni pada ketiga lahan pengamatan tersebut disebabkan oleh keterbatasan lahan talas yang berdekatan dengan lahan padi. Bahkan di lokasi Tamansari, tidak ditemukan adanya serangan hama O. japonica. Menurut Willemse (2001), $O$. japonica merupakan hama utama pada tanaman padi, sedangkan tanaman talas berperan sebagai inang dan tempat peletakkan telur alternatif $O$. japonica. Menurut Doutt (1959), imago betina parasitoid cenderung mencari inang di lingkungan dengan kemungkinan paling besar mengandung inang. Meskipun pada lokasi Kecamatan Bogor Barat sampel yang didapat lebih banyak dari lokasi lainnya, akan tetapi tingkat parasitisasi S. pembertoni di lokasi ini lebih rendah jika dibandingkan dengan lokasi Kecamatan Bogor Selatan. Beberapa faktor mempengaruhi keberadaan dan tingkat parasitisasi parasitoid di suatu lokasi, diantaranya adalah ketersediaan serangga inang, keberadaan tanaman berbunga sebagai penghasil nektar untuk kebutuhan makanan imago parasitoid, dan kemampuan parasitoid 
dalam menemukan inang. Menurut Doutt (1959), distribusi dan keberadaan parasitoid sangat dipengaruhi oleh tanaman sebagai sumber nektar dan keberadaan inangnya.

\section{KESIMPULAN}

Spesies parasitoid yang digunakan dalam penelitian ini adalah $S$. pembertoni. Terdapat pengaruh dari perbedaan umur telur inang yang digunakan terhadap $S$. pembertoni, semakin tua umur telur inang semakin tidak disukai. Dilihat dari beberapa parameter biologi dan tingkat keberhasilan hidupnya di laboratorium serta dengan populasi di lapangan yang dominan, $S$. pembertoni berpotensi dikembangkan sebagai agens hayati untuk mengendalikan $O$. japonica.

\section{UCAPAN TERIMA KASIH}

Terima kasih kepada Kementerian Riset Teknologi dan Pendidikan Tinggi atas beasiswa yang diberikan pada Program Beasiswa Pendidikan Pascasarjana Dalam Negeri Calon Dosen tahun 2013.

\section{DAFTAR PUSTAKA}

Clausen CP. 1940. Entomophagous Insects. New York: McGraw-Hill.

Dangerfield PC, Austin AD, Baker GL. 2001. Biology, Ecology, and Systematics of Australia Scelio Wasp Parasitoids of Locust and Grasshopper Eggs. Collingwood: CSIRO.

Doutt RL. 1959. The biology of parasitic Hymenoptera. Annual Review of Entomology 4:161-182. doi: https://doi.org/10.1146/annurev. en.04.010159.001113.

Field SA, Austin AD. 1994. Anatomy and mechanics of the telescopic ovipositor system of Scelio Latreille (Hymenoptera: Scelionidae) and related genera. International Journal of Insect Morphology and Embryology 23:135-158. doi: https://doi.org/10.1016/0020-7322(94)90007-8.

Godfray HCJ. 1994. Parasitoids, Behavioral and Evolutionary Ecology. New Jersey: Princeton Univ Pr.
Nurwahyudi H. 2003. Dinamika Populasi Oxya spp. (Orthoptera: Acrididae) pada Pertanaman Padi di Desa Cibalumbang Lebak, Kacamatan Darmaga, Kabupaten Bogor. Skripsi. Bogor: Institut Pertanian Bogor.

Pemberton CE. 1933. Introduction to Hawaii of Malayan parasites (Scelionidae) of the Chinese Grasshopper, Oxya chinensis (Thun.) with life history notes. Proceedings of Hawaiian Entomological Society 8:253-264.

Peñaflor MFGV, de Moraes Sarmento MM, Da Silva CSB, Werneburg AG, Bento JMS. 2012. Effect of host egg age on preference, development and arrestment of Telenomus remus (Hymenoptera: Scelionidae). European Journal of Entomology 109:15-20. doi: https://doi.org/10.14411/ eje.2012.003.

Pickford R. 1964. Life history and behaviour of Scelio calopteni Riley (Hymenoptera: Scelionidae), a parasite of grasshopper eggs. The Canadian Entomologist 96:1167-1172. doi: https://doi. org/10.4039/Ent961167-9.

Rasid MR. 2014. Pengamatan Parasitoid Telur Scelio sp. (Hymenoptera: Scelionidae) pada Telur Oxya japonica Thunberg (Orthoptera: Acrididae) Skripsi. Bogor: Institut Pertanian Bogor.

Romani R, Isidoro N, Bin F. 2010. Antennal structures used in communication by egg parasitoids, chapter 3. In: Consoli FL, Parra JRP, Zucchi RA, (Eds.), Progress in Biological Control: Egg Parasitoids in Agroecosystems with Emphasis on Trichogramma. pp. 57-91. Heidelberg: Springer Science.

Salt G. 1961. Competition among insect parasitoids. Symposia of the Society for Experimental Biology 15:96-119.

Timberlake PH. 1931. Three new parasitic Hymenoptera from the Indo-Malayan region. Citrus Experiment Station, Riverside, Calif. Presented by: $\mathrm{OH}$ Swezey at the Meeting of December 3, 1931. 153-162. Available at: http:// hl-128-171-57-22.library.manoa.hawaii.edu/ bitstream/10125/15838/1/PHES08_153-162. pdf. [accessed 21 January 2017].

Wajnberg E. 2010. Genetics of the behavioral ecology of egg parasitoids, chapter 5. In: Consoli FL, Parra JRP, Zucchi RA (Eds.), Progress in Biological Control: Egg Parasitoids in Agroecosystems with Emphasis on Trichogramma. pp. 149-161. Heidelberg: Springer Science.

Willemse LPM. 2001. Fauna Malesiana Guide to the Pest Orthoptera of the IndoMalayan Region. Leiden: Backhuys Pub. 
Yuliani D. 2003. Pengamatan Serangga Predator dan Parasitoid Oxya spp. (Orthoptera: Acrididae) pada Pertanaman Padi dan Talas di Daerah Bogor. Skripsi. Bogor: Institut Pertanian Bogor.
Zuparko RL. 2008. Parasitic Hymenoptera (parasitica). In: Capinera JL (Ed.), Encyclopedia of Entomology, 2 ${ }^{\text {sd }}$ edition. pp. 2730-2736 Florida: Springer Science and Business Media. 